\title{
Ferrochrome Slag Feasibility as a Raw Material in Refractories: Evaluation of Thermo-physical and High Temperature Mechanical Properties
}

\author{
Marjaana Karhu ${ }^{1}$ (1) Bob Talling ${ }^{2} \cdot$ Patrycja Piotrowska $^{2} \cdot$ Alba Matas Adams $^{3} \cdot$ Abirami Sengottuvelan $^{4}$. \\ Elina Huttunen-Saarivirta ${ }^{1} \cdot$ Aldo R. Boccaccini $^{4} \cdot$ Pertti Lintunen ${ }^{1}$
}

Received: 31 July 2019 / Accepted: 18 May 2020 / Published online: 21 May 2020

(c) The Author(s) 2020

\begin{abstract}
This paper reports the characteristics of ferrochrome slag and its feasibility as aggregate in refractories aiming to substitute virgin refractory raw materials. Refractory castable specimens were formulated with ferrochrome slag as an aggregate and commercial calcium aluminate cement as a binder. Objective was to prepare refractory specimens with a maximum slag utilization but simultaneously to sustain good properties, comparable to those of virgin raw material refractory products. Mechanical and thermo-physical properties of the cured, dried and sintered specimens were characterized. Cold crushing strengths of best performing ferrochrome slag containing specimens were higher than $90 \mathrm{MPa}$ and compressive strength values measured at $1200{ }^{\circ} \mathrm{C}$ were over $9 \mathrm{MPa}$. Thermal insulation properties were even better than those of commercial refractory reference, showing thermal conductivity values as low as $\lambda_{\mathrm{RT}-1000{ }^{\circ} \mathrm{C}}=1.3-0.9 \mathrm{~W} / \mathrm{m} \mathrm{K}$. The liquid phase formation above $1200^{\circ} \mathrm{C}$ limits the ferrochrome slag use for refractory applications. Results suggest ferrochrome slag's feasibility as an aggregate raw material for refractory materials up to temperatures of $1200{ }^{\circ} \mathrm{C}$ in air and up to temperatures of $700{ }^{\circ} \mathrm{C}$ in acidic gaseous atmosphere. Possible applications for this kind of novel refractory materials are, e.g., insulating secondary layers or bottom zones in metallurgical processes to substitute virgin refractories. A direct contact to molten metal must be avoided, but they are applicable as, e.g. floorings when exposed only to occasional melt droplets.
\end{abstract}

\section{Graphic Abstract}
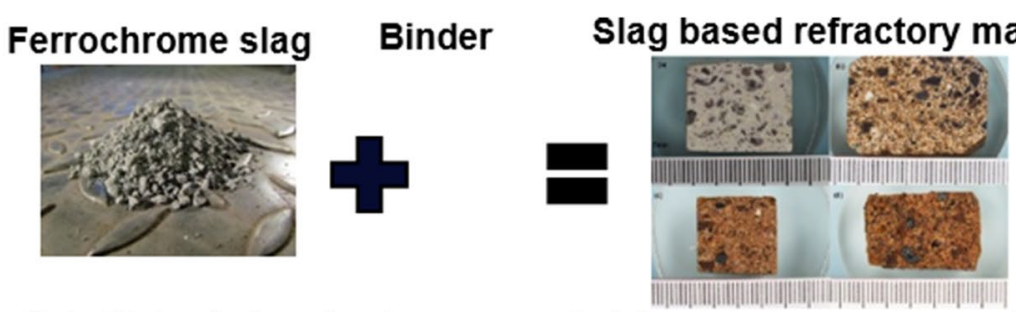

$\checkmark \quad$ Substitute virgin refractory raw materials up to temperatures of $1200^{\circ} \mathrm{C}$

$\checkmark \quad$ Comparable strengths to commercial products CCS $>90 \mathrm{MPa}$

$\checkmark$ Good thermal insulators, thermal conductivity $\lambda_{\mathrm{RT}-1000^{\circ} \mathrm{C}}=1.3-0.9 \mathrm{~W} / \mathrm{m} \cdot \mathrm{K}$

Keywords Slag valorisation $\cdot$ Refractory ceramics $\cdot$ Ferrochrome slag $\cdot$ Electric arc furnace slag

\section{Statement of Novelty}

Marjaana Karhu

marjaana.karhu@vtt.fi

Extended author information available on the last page of the article
Thus, very limited studies have been conducted to investigate $\mathrm{FeCr}$ slag feasibility in high temperature applications, such as in refractory products. This study addressess $\mathrm{FeCr}$ 
slag use as aggregate in refractory castables by investigating comprehensively refractory castables thermo-physical and mechanical properties. To authors' knowlewdge, there is a lack of information of ferrochrome slag utilizing refractory materials behaviour at elevated temperatures. For this reason, mechanical and thermal properties of ferrochrome slag based refractories were evaluates also at high temperatures, resulting novel information about their high temperature behaviour.

\section{Introduction}

Globally $1.6 \mathrm{Gt}$ of steel was produced in 2014 creating 250 $\mathrm{Mt}$ of steel slag as residue [1]. Disposal of the slag is the major issue for steel industry and the utilization of steel slags has been under active research in many years [2]. Most of the slag $(50 \%)$ is used for road projects, sintering, iron making and recycling within the steel plant [3]. High Carbon Ferrochrome $(\mathrm{HCFeCr})$ is the most common alloying material used for the production of different grades of stainless steel. World high carbon ferrochrome production was 6.0 $\mathrm{Mt}$ in 2005 and the generation of ferrochrome (FeCr) slag, the residue generated from $\mathrm{HCFeCr}$ production, amounted 1.1-1.6 t/t FeCr depending on feed materials [4]. Numerous studies are available in the literature about $\mathrm{FeCr}$ slag utilization in road and civil construction purposes, such as coarse aggregate in concrete applications and pavement layers [5-9], partial substitution of fine aggregate sand in concrete $[10,11]$ and raw material in bricks [12]. Kumar et al. $[13,14]$ have reported $\mathrm{FeCr}$ slag use as aggregate in refractory castables replacing partly commercial aggregates use. They reported $50 \mathrm{wt} \%$ of slag use together with $35 \mathrm{wt} \%$ of calcined bauxite in [13] and $45 \mathrm{wt} \%$ of slag and $40 \mathrm{wt} \%$ of calcined bauxite use in [14]. Results for such refractories disclosed compressive strengh values as high as $60 \mathrm{MPa}$, indicating the potential for ferrochrome slag use in refractory products. Thus, very limited studies exist of $\mathrm{FeCr}$ slag feasibility in high temperature applications. This study addresses $\mathrm{FeCr}$ slag use as aggregate in refractory castables by investigating comprehensively refractory castables thermo-physical and mechanical properties. To authors' knowlewdge, there is a lack of information of ferrochrome slag utilizing refractory materials behaviour at elevated temperatures. For this reason, mechanical and thermal properties of ferrochrome slag based refractories were evaluates also at high temperatures, resulting novel information about their high temperature behaviour.

Refractories are ceramic materials that withstand a variety of harsh conditions, including high temperatures, corrosive liquids and gases, abrasive wear, and mechanical and thermal stresses [15]. They are indispensable to all high temperature processes in the production of metals, cement, glass and ceramics as in lining materials for furnaces, kilns, incinerators, and reactors. An enormous variety of refractories exists, designed to meet the temperature and process requirements of each application. Refractory materials are designed so that their properties will be appropriate for the application [16]. Refractory industry is heavily dependent on raw material imports and, within the last years, there has been significant increase in material prices [17]. For refractory industry, the need to secure the availability of raw materials at competitive price has created a strong incentive for exploration of alternative sources of raw materials to substitute virgin raw materials [18] as well as to develop recycling of spent refractories [19].

This paper reports the characteristics of ferrochrome slag and its feasibility as aggregate in refractories aiming to substitute virgin raw materials. Refractory castable specimens were formulated with ferrochrome slag as an aggregate and commercial calcium aluminate cement as a binder. Objective in this study was to prepare refractory specimens with a maximum slag utilization but simultaneously to sustain good properties, comparable to those of virgin raw material products. The testing of refractory properties, in most cases, indicate the performance of a refractory in actual application. Hence, appropriate testing of refractories for predicting properties, closely simulative to their applications, is of great importance [16]. As this study aimed to determine the feasibility of ferrochrome slag to substitute the virgin raw materials in refractories, the effect of slag on refractory specimen properties was investigated and compared with conventional, commercial reference material targeted for similar applications. Mechanical and thermo-physical properties of the cured, dried and sintered specimens were characterized in terms of cold crushing strength, bulk density, porosity, thermal expansion, specific heat capacity and thermal conductivity. Mechanical and thermal properties were evaluated also at high temperatures. In addition, mechanical properties were defined for $\mathrm{FeCr}$ slag based refractories exposed to corrosive gaseous atmosphere.

Table 1 Approximate chemical composition of the raw materials (\%)

\begin{tabular}{lllll}
\hline & FeCr slag & EAF slag & Secar71 & Reference \\
\hline $\mathrm{SiO}_{2}$ & 30 & 10 & - & 44.5 \\
$\mathrm{Al}_{2} \mathrm{O}_{3}$ & 26 & 29 & 70 & 52 \\
$\mathrm{MgO}$ & 23 & 7 & - & - \\
$\mathrm{CaO}$ & 2 & 45 & 30 & 1.5 \\
$\mathrm{Cr}_{2} \mathrm{O}_{3}$ & 8 & - & - & - \\
$\mathrm{Fe}_{2} \mathrm{O}_{3}$ & 4 & 2 & 0.1 & 0.5 \\
\hline
\end{tabular}




\section{Materials and Experimental Procedures}

\section{Raw Materials}

In this study, ferrochrome slag, originating from high carbon ferrochrome production, was used as aggregate and commercially available calcium aluminate cement (Secar 71 provided by Kerneos) was used as a hydraulic binder in refractory castable specimen formulation. Another steel industry slag, electric arc furnace, EAF, slag originating from carbon steel production was used as fine fraction for castables. As a reference, commercial refractory castable Calde Flow LF50A provided by Calderys was used. Table 1 shows approximate chemical compositions of the raw materials, the total oxide concentrations measured with X-ray fluorescence (XRF) method.

Particle packing optimization of refractory castables covers the selection of right size and amount of various particles [20]. The particles size distribution is selected to fill up the voids between large particles with smaller particles and thus to increase the particle packing density. In this study, Elkem Materials Mixture Analyser Software (EMMA) was used for optimal particle packing calculations in order to formulate the optimal recipes with the right size and amount of various particles using distribution coefficient (q) value of 0.30. Particle size distribution optimization was based on packing models and curves developed by Andreassen [21]. The optimization curves were combined in such a way that the total particle size distribution of the mixture is closest to an optimum curve. In this study, maximum slag utilization was targeted and the $\mathrm{FeCr}$ aggregate percentage of $81.8 \mathrm{wt} \%$ was kept constant throughout the study. The ratio between cement and the aggregates was locked to 1:4.5 on weight basis. The batch compositions listed in Table 2 were formulated. The composition of Castable1 was formulated using only $\mathrm{FeCr}$ slag as aggregate and commercial cement as binder. Castable2 was prepared using $0.15 \mathrm{wt} \%$ commercial dispersant (provided by BASF, Castament [22]) in order to evaluate the effect of dispersant use on aggregate binder compatibility and hence strength values. BASF Castament dispersants consisted of polymers based on polyethylene glycol. They are developed to disperse calcium aluminate cement particles and aggregates in order to improve the

Table 2 Batch composition of slag based specimens as wt $\%$

\begin{tabular}{llllll}
\hline Sample code & FeCr slag & EAF slag & Secar71 & Dispersant & w/c (g/g) \\
\hline Castable1 & 81.8 & - & 18.2 & No & 0.51 \\
Castable2 & 81.8 & - & 18.2 & Yes & 0.44 \\
Castable3 & 81.8 & 1.8 & 16.4 & No & 0.51 \\
Castable4 & 81.8 & 3.6 & 14.5 & No & 0.51 \\
\hline
\end{tabular}

rheological properties of castables in refractory applications [22]. In the compositions of Castable 3 and Castable4, part of the commercial cement (10\% and 20\%) was replaced by fine EAF slag fraction. Water to cement ratio was experimentally locked to 0.51 for Castables 1,3 and 4 and to 0.44 for Castable2.

\section{Preparation of Refractory Castable Specimens}

The $\mathrm{FeCr}$ slag fine aggregates $0-4 \mathrm{~mm}$ were selected for study. At first, the $\mathrm{FeCr}$ slag was dried for $7 \mathrm{~h}$ at $105^{\circ} \mathrm{C}$ and sieved to the particle size below $4 \mathrm{~mm}$. EAF slag was milled by means of the disintegrator DESI $15 / 16 \mathrm{C}$ to the particle size below $75 \mu \mathrm{m}$. Refractory castable specimens were prepared according to standard EN 196-1 [23]. A standard steel mould with the size of $40 \times 40 \times 160 \mathrm{~mm}^{3}$ was used for mixed compositions. Castable were perepared by mechanical mixing and compacted in a mould using a standard jolting apparatus as described in standard. Specimens were first cured for $24 \mathrm{~h}$ in the moulds in a curing cabinet $(\mathrm{RH}>95 \%)$ at room temperature. Then the specimens were removed from the mould and left for another $24 \mathrm{~h}$ in the curing cabinet in a plastic bag at room temperature. After that, specimens were moved to drying oven for $7 \mathrm{~h}$ at $105^{\circ} \mathrm{C}$. The dried specimens were then sintered in air atmosphere by slowly heating them to $540{ }^{\circ} \mathrm{C}$ and kept at this temperature for $3 \mathrm{~h}$, then heated to $1200^{\circ} \mathrm{C}$ and kept there for another $3 \mathrm{~h}$.

\section{Characterization Methods}

FeCr slag was characterized by microstructural and compositional studies as well as thermal analyses to find out its characteristics. Microstructural investigations were performed using a field-emission scanning electron microscope (FESEM Zeiss ULTRAplus) equipped with an energy dispersive spectrometer (EDS, INCA x-act silicon-drift detector (SDD), Oxford Instruments). The identification of crystalline phases was done by using an X-ray diffractometer (XRD, Empyrean, PANanalytical B.V., ALMELO, Netherlands) with $\mathrm{Cu}-\mathrm{K} \alpha$ radiation source, and analysed using HighScore Plus software. The thermal behaviour was studied using thermogravimetric analysis (TGA, Netzsch STA 449 F1 Jupiter) giving also a simultaneous Differential Scanning Calorimetry (DSC) signal. The measurements were made in air and argon atmospheres at a heating rate of $10^{\circ} \mathrm{C} / \mathrm{min}$.

In order to evaluate the strength behaviour for slag-based refractory specimens, six specimens were prepared from the Castable 1 composition mixture, and their compressive strengths were recorded after chosen steps. The preparation of six specimens took place on day 1 . After $24 \mathrm{~h}$ of curing in the moulds placed in the curing cabinet, specimens were removed from moulds and the compression test was carried out for one of the six specimens, with the strength 
value being recorded as the 1-day compressive strength (step1). On day 2, five of the specimens were left in the curing cabinet in a plastic bag. One of the five specimen was kept separately in the curing cabinet for the measurement of 7 -day compressive strength (step2). On day 3, four remaining specimens were moved to drying oven where they are kept for $7 \mathrm{~h}$ at $105{ }^{\circ} \mathrm{C}$. At the end of the day after drying, one of the specimens was subjected to the determination of compression strength at $105^{\circ} \mathrm{C}$ (step3). On day 4, three of the dried specimens were slowly heated to $540{ }^{\circ} \mathrm{C}$ and kept at the temperature for $3 \mathrm{~h}$. On day 5 , one specimen from day 4 was heated to $1000{ }^{\circ} \mathrm{C}$, the second specimen was heated to $1200{ }^{\circ} \mathrm{C}$, and the third specimen from day 4 was used for the compression test at $540{ }^{\circ} \mathrm{C}$ (step4). On the next day, the cooled specimens were subjected to compression strength determination, and their strength values were recorded for $1000{ }^{\circ} \mathrm{C}$ (step5) and for $1200{ }^{\circ} \mathrm{C}$ (step6).

The microstructural, physical, mechanical and thermal properties of cured, dried and sintered refractory castable specimens were characterized. Metallographic cross sections were produced by casting the cut sections of specimens in Epofix cold setting resin under low pressure. The castables were then ground and polished. An OLYMPUS digital camera was used for photographing of cross sections. The cross sections were also analysed using FESEM, for which the castables were carbon coated for electrical conductivity. Apparent solid density, bulk density and open porosity of the specimens were investigated according to Archimedes principle following the ISO18754 standard. Thermal expansion coefficient $\alpha$ for the specimens was measured by dilatometry using a Netzsch Dilatometer DIL 402C. The used sample size for the measurements was rectangular $25 \mathrm{~mm} \times 5 \times 5$ or cylindrical, $25 \times 5 \mathrm{~mm}$ diameter, cut by a diamond saw, and the heating rate was $5{ }^{\circ} \mathrm{C} / \mathrm{min}$. Specific heat capacity and thermal conductivity were measured by laser flash analysis (LFA 457 Microflash, Netzsch) in argon atmosphere for the samples of the size $10 \times 10 \times 2 \mathrm{~mm}^{3}$. Samples were prepared by a hollow drill and measured in the temperature range from $21{ }^{\circ} \mathrm{C}$ up to $1000{ }^{\circ} \mathrm{C}$. Cold crushing strength of the specimens was tested based on the standard EN 196-1 [23] using uniaxial strength tester. The compression tests were carried out at the constant load rate of $2.4 \mathrm{kN} / \mathrm{s}$ as indicated in the standard. For high temperature mechanical tests, cubic samples were prepared from sintered castables. To obtain the desired sample size $\left(10 \times 10 \times 10 \mathrm{~mm}^{3}\right)$, a diamond saw with a blade thickness of $0.5 \mathrm{~mm}$ was used using a slow cutting speed. The tests were done under argon atmosphere at $1200{ }^{\circ} \mathrm{C}$, with an initial pinchload of $-0.05 \mathrm{kN}$ and a heating rate of $10^{\circ} \mathrm{C} / \mathrm{min}$. Once the temperature was reached, compression was performed at a displacement rate of $0.2 \mathrm{~mm} /$ $\mathrm{min}$. All the measurements were done in furnace using an Instron frame with a $4 \mathrm{MPa}$ loading cell. Exposure tests for the samples of size $20 \times 20 \times 24 \mathrm{~mm}^{3}$ were performed in

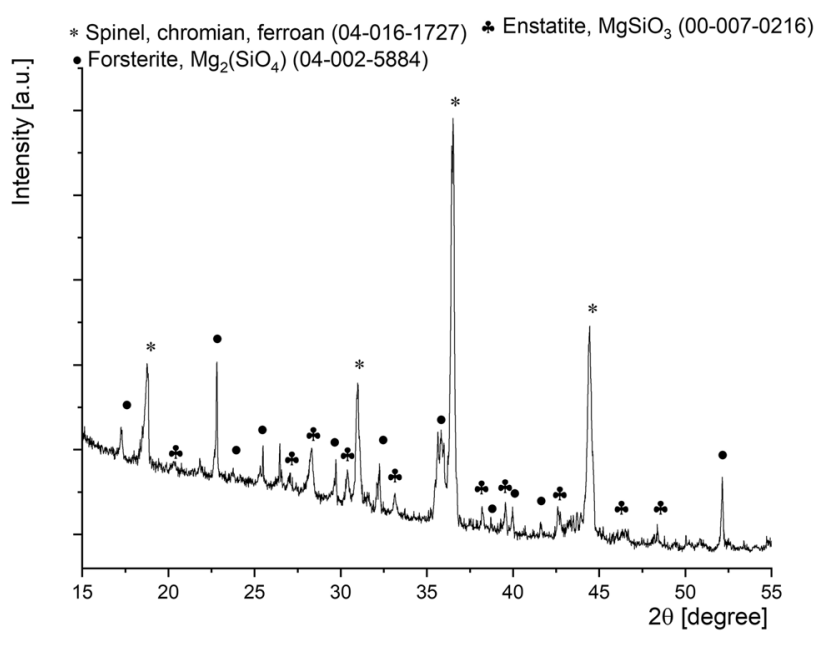

Fig. 1 XRD pattern for the ferrochrome slag

$\mathrm{HCl} / \mathrm{SO}_{\mathrm{x}}$ gas mixture with $15 \%$ humidity at $700{ }^{\circ} \mathrm{C}$ temperature for $168 \mathrm{~h}$, after which the strength values were recorded for the exposed specimens.

\section{Results and Discussion}

\section{Characterization of the FeCr Slag}

Figure 1 presents $\mathrm{X}$-ray diffraction (XRD) pattern for $\mathrm{FeCr}$ slag. Spinel phases (chromian, ferroan) $(\mathrm{Mg})(\mathrm{Al}, \mathrm{Cr})_{2} \mathrm{O}_{4}$ appeared as main crystalline peaks. Other identified phases included forsterite $\mathrm{Mg}_{2} \mathrm{SiO}_{4}$ and enstatite $\mathrm{MgSiO}_{3}$. Additionally, the XRD spectra showed a slight increase in the overall intensity of the curve at low $2 \theta$ values which indicates the presence of an amorphous phase.

Figure 2 shows FESEM (AsB) micrographs of the $\mathrm{FeCr}$ slag cross section with two different magnifications. Microstructural examinations revealed clearly that microstructure of the slag includes several crystalline phases surrounded by an amorphous glassy phase. Elemental maps disclosed that aluminium is concentrated, together with chromium and magnesium, on larger separate quadrilateral-shaped crystals, most likely spinel $(\mathrm{Mg})(\mathrm{Al}, \mathrm{Cr})_{2} \mathrm{O}_{4}$ phase. Magnesium was concentrated on elongated needle-like crystals together with silicon, most likely being forsterite, $\mathrm{Mg}_{2} \mathrm{SiO}_{4}$, or enstatite, $\mathrm{MgSiO}_{3}$, phases detected by XRD analyses. Iron was detected in separate spots, seen in the brightest contrast in SEM images. Crystalline phases were surrounded by silicon-rich amorphous glass phase, seen in darker contrast in SEM images. The shape of the XRD curve supports the presence of amorphous phase besides the crystalline phases. The mineralogy of $\mathrm{FeCr}$ slag was characterized in detail by Makkonen and Tanskanen [24] who have suggested similarly that common phases in the slag are $\mathrm{Fe}-\mathrm{Mg}-\mathrm{Cr}-\mathrm{Al}$-spinels, 

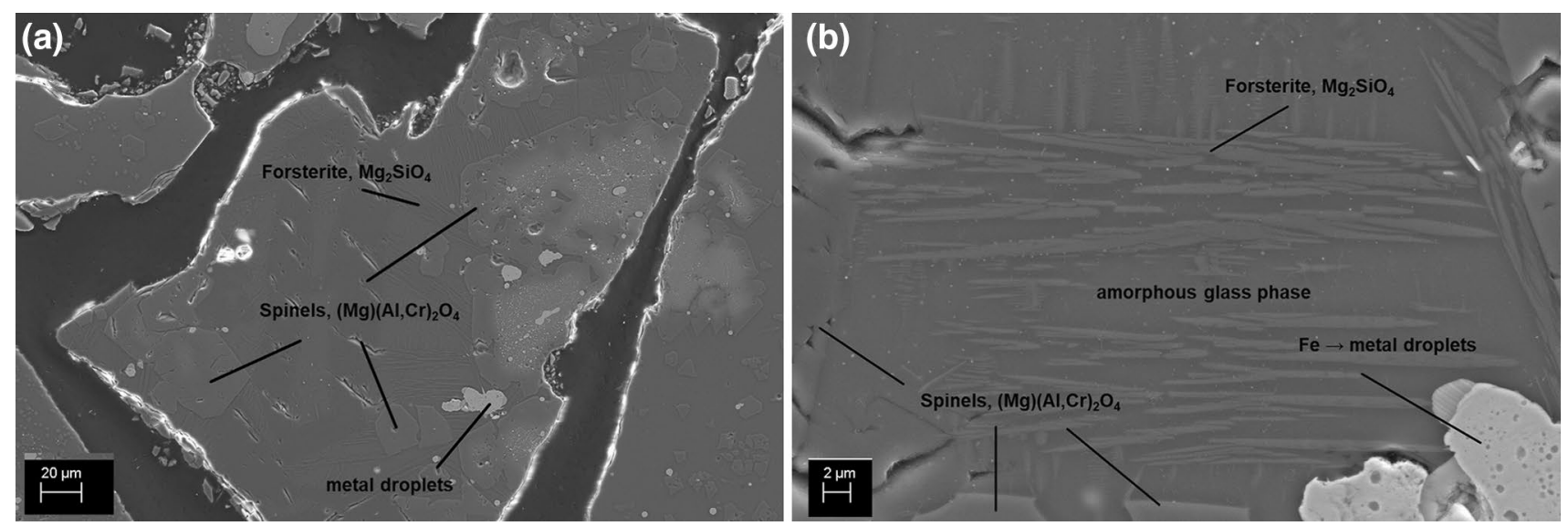

Fig. 2 FESEM images (AsB) of the cross-section of FeCr slag with different magnifications

(a)

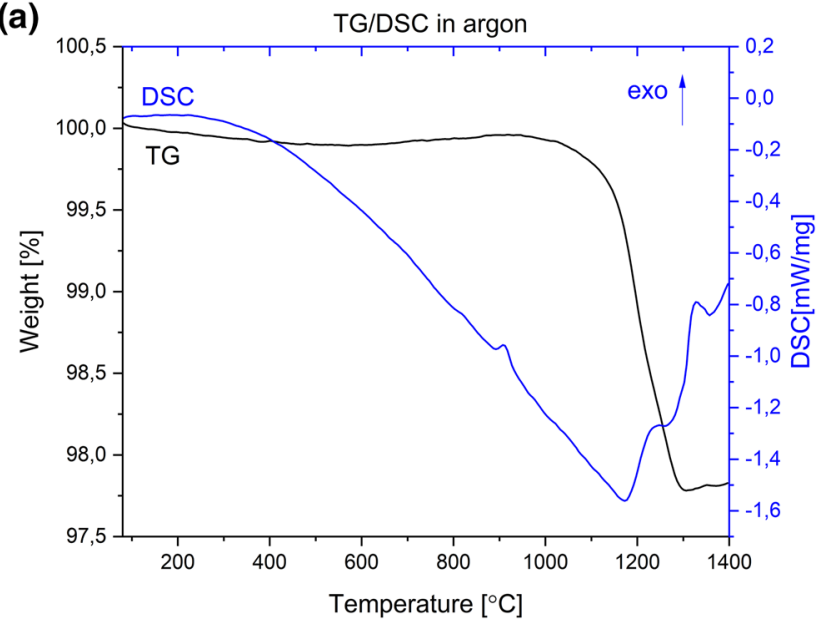

Fig. 3 TG/DSC curves for FeCr slag $\mathbf{a}$ in $\operatorname{argon}$ and $\mathbf{b}$ in air

forsterite $\left(\mathrm{Mg}_{2} \mathrm{SiO}_{4}\right), \mathrm{Mg}$-silicates and metal droplets. With fast cooling rates, the slag is not totally crystalline, with amorphous glass phase being solidified between the grains. The amount of amorphous glass phase depends on the cooling rate being typically between 60 and $70 \%$ in $\mathrm{FeCr}$ slag [24].

Figure 3 shows the TG/DSC measurement curves of the $\mathrm{FeCr}$ slag measured in argon and air atmospheres. In both atmospheres, an exothermic peak was detected in DSC curves above $900{ }^{\circ} \mathrm{C}$ similarly than in the study Zelic [5]. Additionally, in air, the weight loss curve started to increase slightly above $400{ }^{\circ} \mathrm{C}$ showing also a small exothermic peak in the DSC curve. In air, the weight loss curve continued to increase with increase in temperature, relating most probably to metal iron droplets oxidation detected in microstructure observations. In both atmospheres, peaks observed in DSC curves above $1200{ }^{\circ} \mathrm{C}$ were probably related to liquid slag phase formation, with temperature increases increasing the

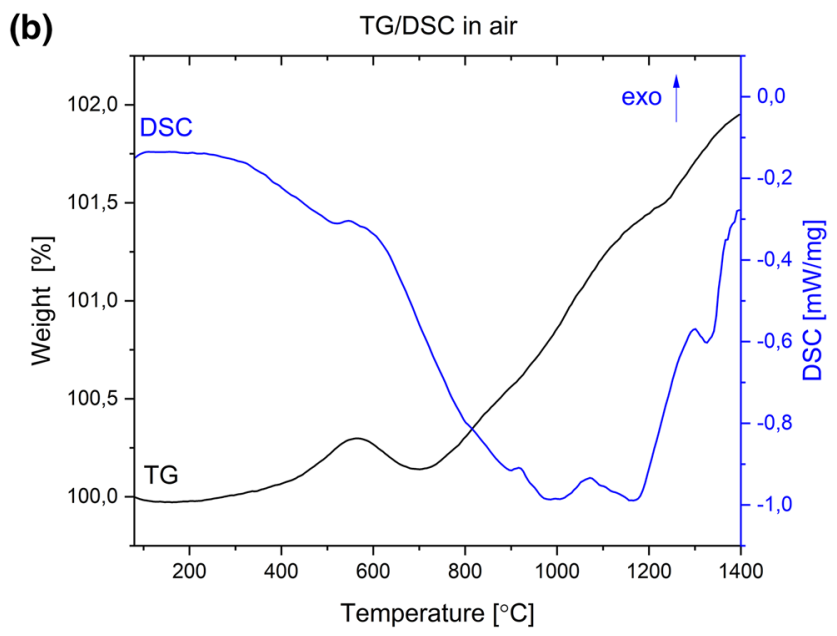

content of liquid phase. In the study by Zelic [5] FeCr slag melting point was reported to fall in the temperature range of $1200-1400{ }^{\circ} \mathrm{C}$. The liquid phase formation at high temperatures restrains the use of $\mathrm{FeCr}$ slag-based materials for structural applications. Refractory systems should be designed in such a way that the maximum temperature attainable in the system is lower than the softening or melting temperature of the refractory ingredients: the binder and the aggregates [16]. Thus these results suggest that maximum service temperature for these type of novel $\mathrm{FeCr}$ slag based refractory material is $1200{ }^{\circ} \mathrm{C}$.

\section{Properties of the Sintered Refractory Specimens}

Figure 4 shows macroscopic cross-sectional images of sintered refractory castable specimens for (a) Reference

(b) Castable 1 (c) Castable1 after reheating to $1260{ }^{\circ} \mathrm{C}$ and

(d) Castable 1 after reheating to $1320^{\circ} \mathrm{C}$. Images revealed 


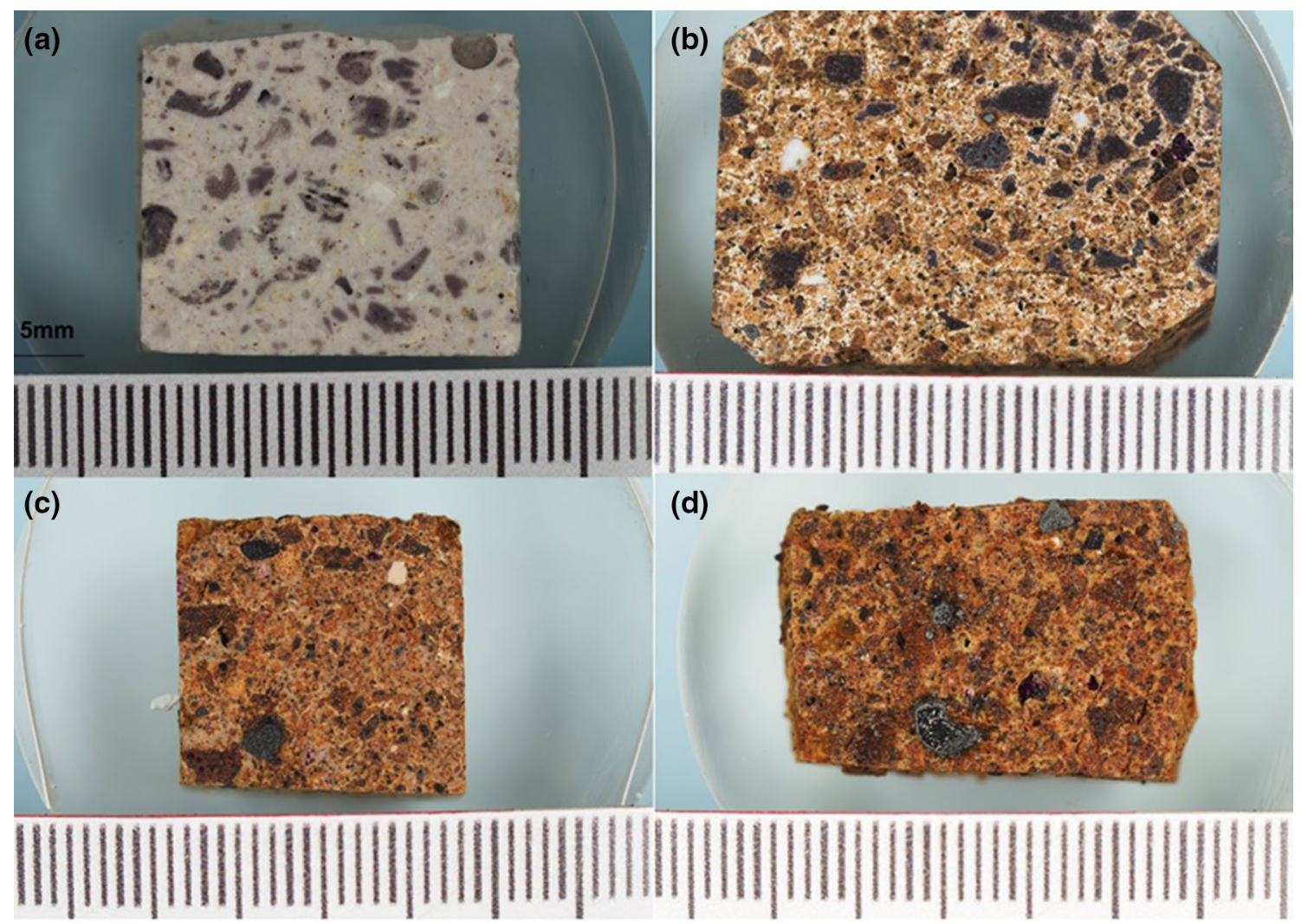

Fig. 4 Macroscopic images of sintered refractory specimen cross sections a Reference, b Castable1, $\mathbf{c}$ Castable1 after reheating at $1260{ }^{\circ} \mathrm{C}$ and $\mathbf{d}$ Castable1 after reheating at $1320^{\circ} \mathrm{C}$
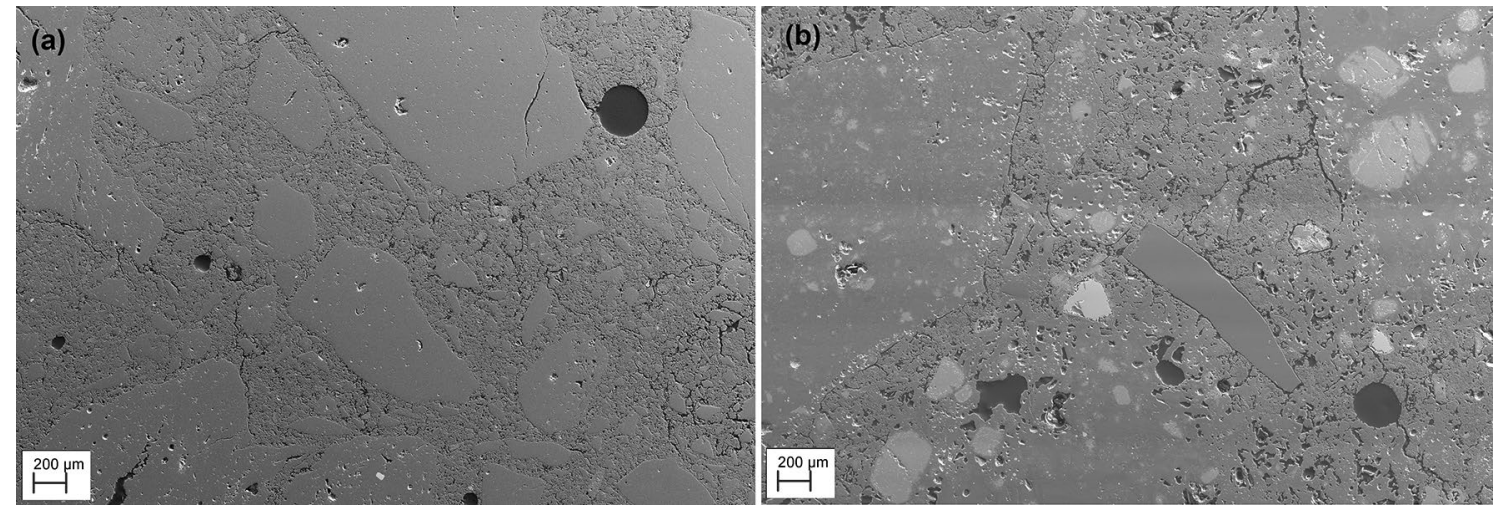

Fig. 5 FESEM cross-sectional micrographs of sintered specimens a Reference, $\mathbf{b}$ Castable2

that both the Reference and Castable1 specimens showed typical refractory material cross-sections, including aggregates and surrounding binder phases. Reheating tests for sintered Castable 1 specimens up to temperatures $1260{ }^{\circ} \mathrm{C}$ and $1320{ }^{\circ} \mathrm{C}$ were made in order to investigate the liquid phase formation which was observed in DSC curves for $\mathrm{FeCr}$ aggregates. Reheating to $1320{ }^{\circ} \mathrm{C}$ revealed clearly the melting of both slag aggregates and surrounding binder phases, which strengthens the observation of maximum service temperature in DSC curves.

Figure 5 shows FESEM images of sintered cross-sectional specimens of (a) Reference and (b) Castable2. FESEM 


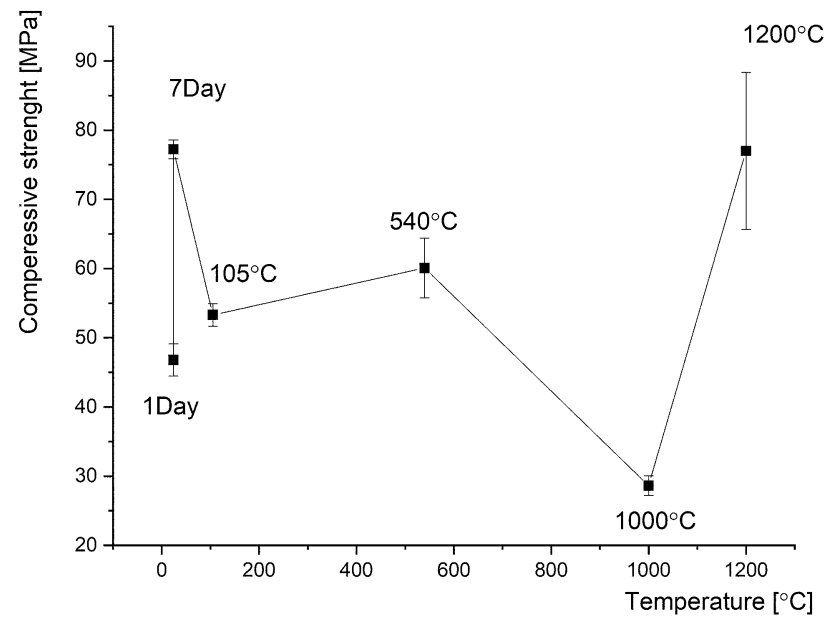

Fig. 6 Strength development curve of slag based Castable1 mixture composition

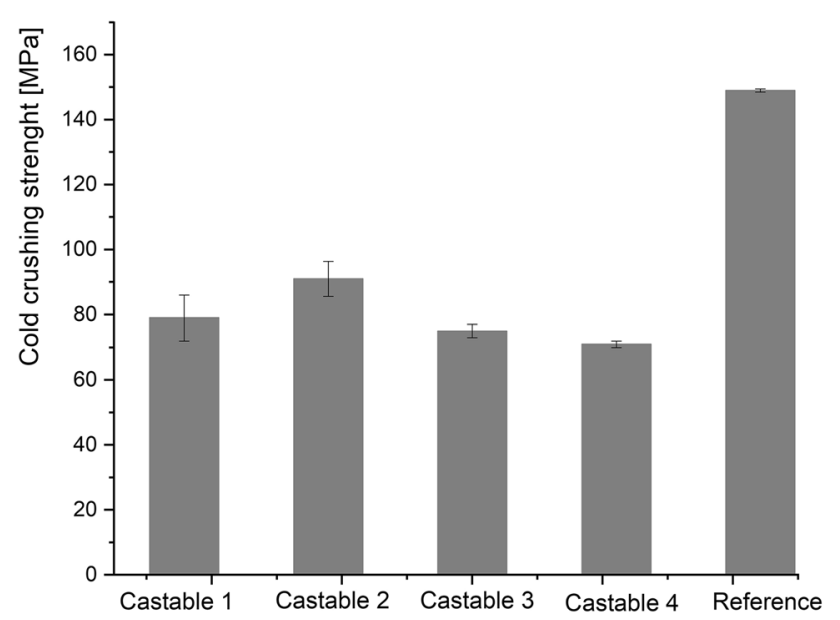

Fig. 7 Cold crushing strengths of slag based-castables and the Reference

micrographs revealed that for the Reference, the compatibility between the binder and the aggregates is good, as charged based on the sharp phase interfaces in Fig. 5a. This is likely a result from long development and surface optimization work for commercial product. For slag-based Castable2 specimen (Fig. 5b), clear cracks at the binder-aggregate interfaces were detected. However, the binder was evenly distributed between the aggregates of different size fractions.

\section{Strength Development Curves}

Figure 6 shows strength development curve for Castable1 composition mixture as a function of temperature. Ceramic bonded or fired refractories are formed at high temperatures using binders and a sintering process [19]. As observed at
$1000{ }^{\circ} \mathrm{C}$ no ceramic bonding has not yet developed. At $1200{ }^{\circ} \mathrm{C}$ temperature, higher strength values suggested that ceramic bonds have been formed and full strength of refractory castables has been achieved.

\section{Cold Crushing Strengths}

The cold compressive strength or cold crushing strength (CCS) of a refractory material is an indication of its suitability for the use as refractory. It is a combined measure for the strength of the aggregate grains and the bonding system [16]. CCS values recorded for sintered specimens are presented in Fig. 7. The results are average of four specimens. It can be observed that the best performing slag-based Castable2 showed average CCS value of $91 \mathrm{MPa}$. Strength value was clearly below the strength recorded for the commercial refractory reference material, $149 \mathrm{MPa}$, but notably higher than the highest strength value, $60 \mathrm{MPa}$, reported in the studies by Kumar et al. [13, 14] for FeCr slag-utilizing castables. According to CCS values, the use of dispersant (in Castable2) increased the average compressive strength value from 79 (Castable1) to $91 \mathrm{MPa}$ (Castable2). Commercial dispersant (BASF Castament) has been developed to disperse calcium aluminate cement particles and aggregates in order to improve the rheological properties of castables in refractory applications [22]. The differences between the performance of Castable 2 and the Reference specimen may be explained by the still poorer compatibility of the binder and aggregate phases of Castable2, as evaluated based on the phase interface appearance (Fig. 5) although the recorded strength values as high as $91 \mathrm{MPa}$ indicate that the strength of the aggregate grains and also of the bonding system are at the acceptable level. By further improving the binder-aggregate compatibility with optimal additives, it can be assumed that

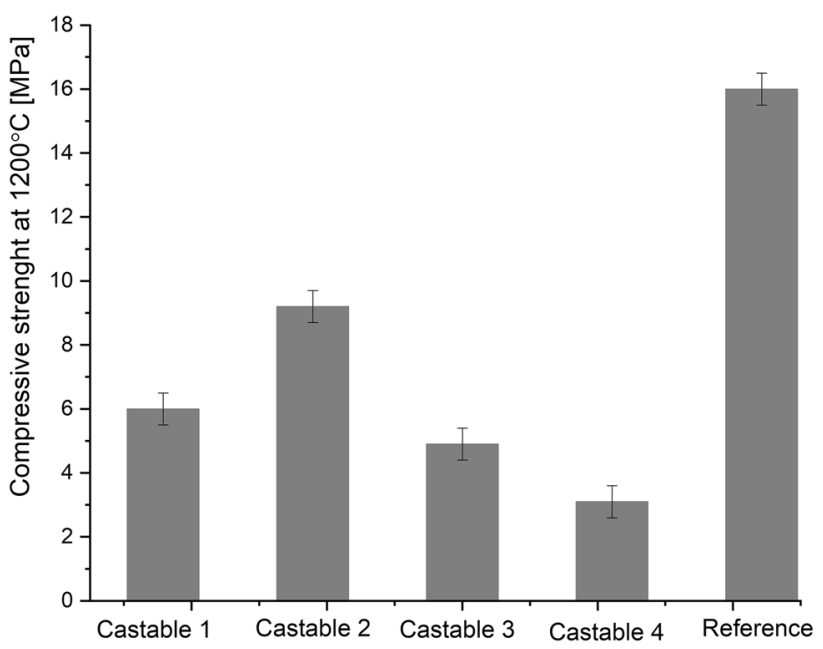

Fig. 8 Compressive strengths measured at $1200^{\circ} \mathrm{C}$ 
Table 3 Apparent solid density, bulk density and open porosity of refractory specimens

\begin{tabular}{llll}
\hline Sample code & $\begin{array}{l}\text { Apparent solid } \\
\text { density }\left(\mathrm{g} / \mathrm{cm}^{3}\right)\end{array}$ & $\begin{array}{l}\text { Bulk density }(\mathrm{g} / \\
\left.\mathrm{cm}^{3}\right)\end{array}$ & Open porosity $(\%)$ \\
\hline Castable1 & $2.96 \pm 0.01$ & $2.35 \pm 0.04$ & $20.66 \pm 1.32$ \\
Castable2 & $2.92 \pm 0.03$ & $2.39 \pm 0.07$ & $17.33 \pm 1.28$ \\
Castable3 & $2.97 \pm 0.03$ & $2.36 \pm 0.05$ & $20.57 \pm 0.77$ \\
Castable4 & $2.99 \pm 0.02$ & $2.33 \pm 0.02$ & $22.18 \pm 0.88$ \\
Reference & $2.78 \pm 0.01$ & $2.33 \pm 0.02$ & $16.12 \pm 0.64$ \\
\hline
\end{tabular}

even higher strength values may be reached. According to CCS results, it seems that $10 \%$ cement replacement by fine EAF slag (Castable3) is possible, still keeping almost the same average strength level for the castables, $75 \mathrm{MPa}$ vs. 79 for Castable1. The higher cement replacement (Castable4) resulted in lower average strength value of $71 \mathrm{MPa}$.

In recent years, more importance has been given to high-temperature strengths of refractories rather than cold strength values, since refractories are used at elevated temperatures [16]. Figure 8 shows the compressive strengths of sintered slag based castables and the Reference measured at the temperature of $1200{ }^{\circ} \mathrm{C}$. Recorded strengths at $1200{ }^{\circ} \mathrm{C}$ were one tenth of corresponding value measured at room temperature. Also at $1200{ }^{\circ} \mathrm{C}$ the highest average strength value for slag-based castable was obtained for Castable2, 9.2 MPa, followed by Castable 1 (6.0 MPa). Strength results measured at $1200{ }^{\circ} \mathrm{C}$ revealed more clearly that cement replacement by fine EAF slag decreased the strength values. 10\% cement replacement by fine EAF slag (Castable3) decreased the average compressive strength to $4.9 \mathrm{MPa}$ and $20 \%$ cement replacement (Castable4) even lower, to 3.1 $\mathrm{MPa}$.

\section{Apparent Solid Density, Bulk Density and Open Porosity}

The values of apparent solid density, bulk density, and open porosity for slag-based castables and the Reference are shown in Table 3. The results are average of three samples. Typically, the values of density and porosity are used to recommend the refractories for specific applications [16]. In general, the higher the density, the lower the porosity and also, other physical properties, such as strength, are typically related to the density and porosity values. Table 3 shows that bulk density values were of the same order for slag-based castables and the commercial Reference, around $2.35 \mathrm{~g} / \mathrm{cm}^{3}$. These values are typical for the alumino-silicate-based, dense refractory castables used as structural components in heat-treatment furnaces and kilns [16]. The Castable2 showed a slightly higher density value of $2.39 \mathrm{~g} /$ $\mathrm{cm}^{3}$ but featured also the highest variation in the values, which could partly explain the result. Nevertheless, for

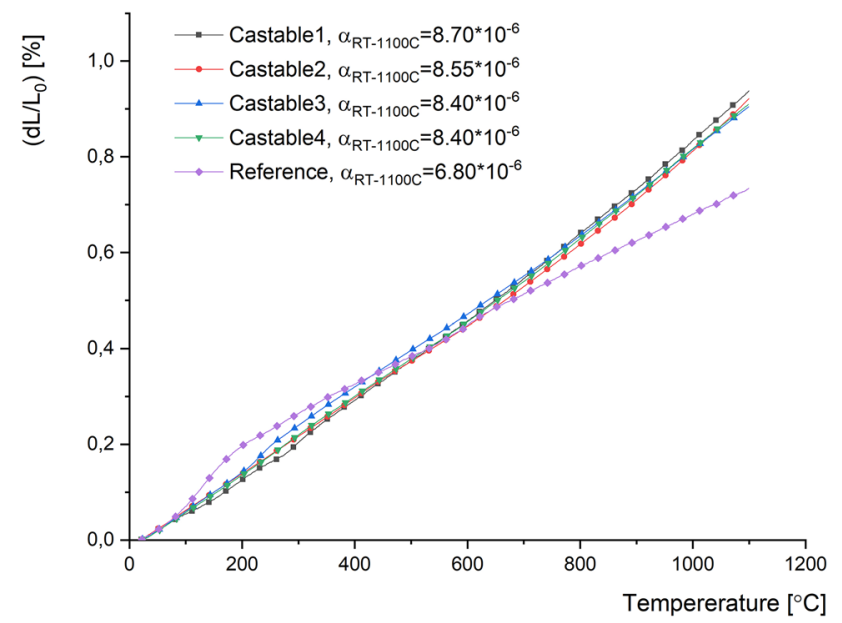

Fig. 9 Thermal expansion of sintered specimens measured by dilatometry

the best performing (highest strength) slag-based castable, Castable2, the open porosity value of $17.3 \%$ was of the same order with the commercial Reference, $16.1 \%$. For other slagbased castables, the porosity values were approximately $20 \%$ (Castable1 and Castable3; or even higher (22\% for Castable4). Thus by increasing the cement replacement with fine EAF slag fraction, the porosity is increased and the density values of the castable are lowered.

\section{Thermal Expansion}

Figure 9 shows the linear thermal expansion of sintered specimens measured by dilatometry. Thermal expansion coefficients, $\alpha$, of the specimens were determined in the

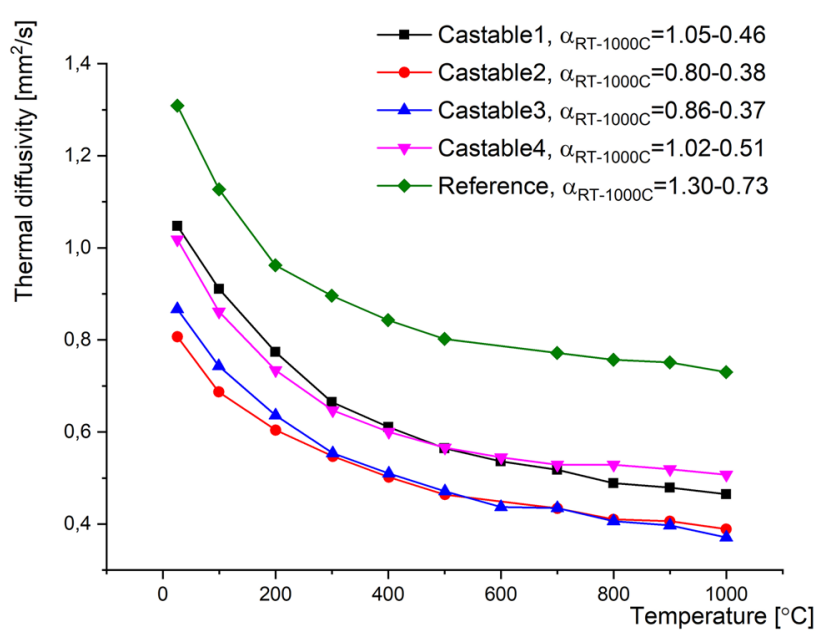

Fig. 10 Thermal diffusivity measured as function of temperature for slag-based castables and Reference 


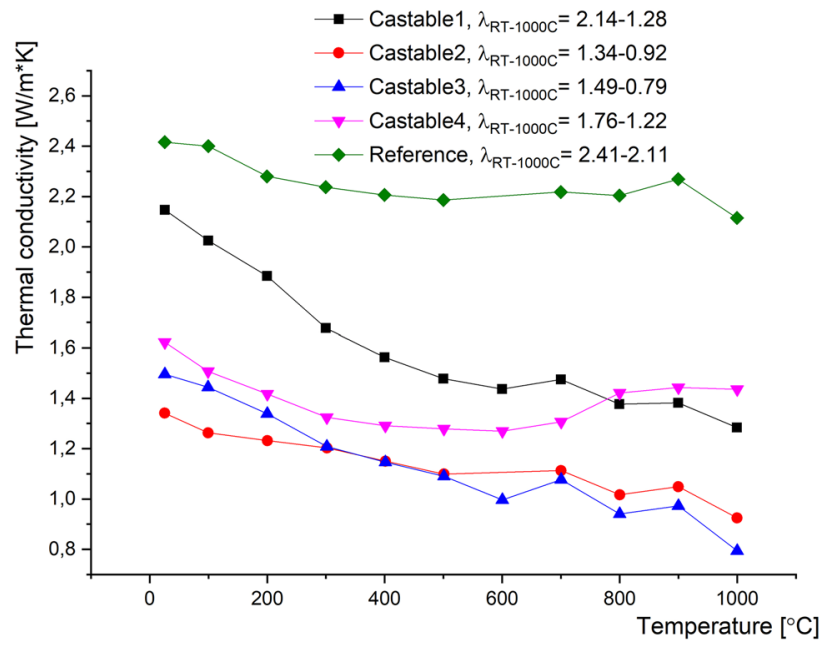

Fig. 11 Thermal conductivity measured as function of temperature for slag based castable and Reference

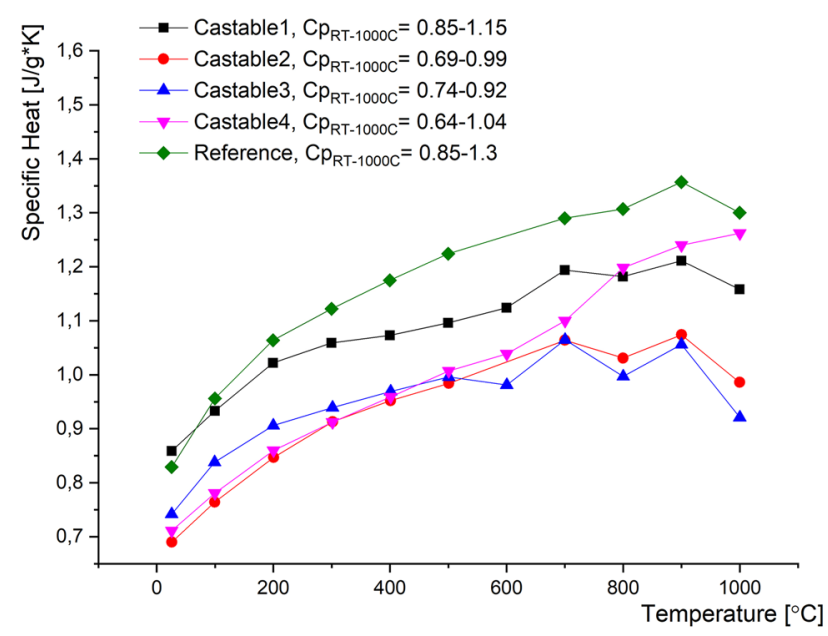

Fig. 12 Specific heat capacity as function of temperature for slagbased castables and the Reference

temperature interval from room temperature up to $1100^{\circ} \mathrm{C}$. Most refractory materials expand when heated and thus, when refractories are installed at room temperature, the whole structure expands and tightens up when heated [16]. Figure 9 shows that all the FeCr slag-based specimens exhibited linear expansion and the recorded thermal expansion coefficient values were at the level comparable to those for the Reference.

\section{Specific Heat Capacity and Thermal Conductivity}

Figures 10, 11 and 12 show thermal diffusivity, thermal conductivity and specific heat capacity as a function of temperature for the sintered specimens. In all cases, thermal diffusivity values in Fig. 10 revealed a slight decrease with increase in temperature. Slag-based castables featured somewhat lower thermal diffusivity values as compared to commercial Reference, for which the values ranging between 1.3 and $0.7 \mathrm{~mm}^{2} / \mathrm{s}$ were obtained. Among the slag-based castables, the thermal diffusivity values closest to the commercial reference were recorded for Castable1, ranging from 1.1 to $0.5 \mathrm{~mm}^{2} / \mathrm{s}$. The thermal diffusivity values for the slagbased Castable2 (with the best strength properties) showed the lowest thermal diffusivity values, from 0.8 to $0.4 \mathrm{~mm}^{2} / \mathrm{s}$.

Thermal conductivity is a measure of the refractory materials' ability to conduct heat from the hot to the cold face when it is exposed to high temperatures [16]. Low thermal conductivity values implies good thermal insulation capability for refractory materials. Typically when thermal insulation is needed for refractory material, insulating refractory materials are formulated for low relative thermal conductivity and not for strength resistance. The majority of insulating castables are alumino-silicate- based or high alumina castables, having densities between 0.4 and $1.45 \mathrm{~g} / \mathrm{cm}^{3}$ and corresponding porosities of $45-85 \%$. Thus insulating castables show much lower densities and higher porosities than dense castables. Generally when density increases and porosity decreases, thermal conductivity will increase [16]. Thermal conductivity values shown in Fig. 11 disclosed a slight overall decrease in with a shift towards higher temperatures. Slag-based Castable2 exhibited the lowest thermal conductivity values, from 1.3 to $0.9 \mathrm{~W} / \mathrm{mK}$, which were much lower than for the commercial Reference (2.4-2.1 W/ $\mathrm{mK})$. However, all slag-based castables showed thermal conductivity values lower than the Reference. Thermal conductivity values of slag-based Castable 2 are comparable to values shown in literature for alumina based insulating castables which show thermal conductivity value of $1.2 \mathrm{~W} /$ $\mathrm{mK}$ at $200{ }^{\circ} \mathrm{C}$ but have much lower density value of $1.2 \mathrm{~g} /$ $\mathrm{cm}^{3}$ [16]. These results indicate a good thermal insulation capability for $\mathrm{FeCr}$ slag based castables and their suitability in the use as aggregate in refractory castables for insulation purposes and simultaneously having sufficient strength for structural component also. Lower thermal conductivity values for $\mathrm{FeCr}$ slag compared with natural material granite has been reported also by Niemelä and Kauppi [4] for civil engineering and road construction uses.

The values of specific heat shown in Fig. 12 revealed a slightly increasing values with rise in temperature. Similar results were obtained for EAF slag reported in the literature [25].

\section{Exposure Tests for Corrosive Atmosphere}

Corrosion resistance is one of the most important characteristics of refractories, thus the test conditions have to be designed so that they closely simulate the conditions that the 
refractories experience during the use [16]. Thermogravimetric analyses of the $\mathrm{FeCr}$ slag-based refractories indicate that their maximum service temperature is $1200{ }^{\circ} \mathrm{C}$. Thus in common metallurgical processes that operate at temperatures above $1200{ }^{\circ} \mathrm{C}$, direct exposure to molten metal and slag should be avoided. However, potential applications may involve exposure to gaseous atmosphere, the temperature of which is typically lower than that of liquid phases. For that reason, corrosion tests were performed to predict the behaviour of $\mathrm{FeCr}$ based castables in acidic gaseous atmosphere. During the test procedure, samples were exposed to the gas mixture of $15 \%$ humidity and $\mathrm{HCl} / \mathrm{SO}_{\mathrm{x}}$ at $700{ }^{\circ} \mathrm{C}$ temperature for $168 \mathrm{~h}$. With visual inspection, no corrosion effects were seen on the surface of the test samples after the exposure. Mechanical tests were performed for the exposed corrosion samples in order to evaluate the effect of corrosive atmosphere on mechanical properties. According to results, corrosion exposure caused no effect on strength valuesneither for the slag-based castables nor for the commercial reference. These investigations indicate that the resistance to acidic gaseous atmosphere for $\mathrm{FeCr}$ slag based materials is at least at comparable level to the commercial materials.

\section{Conclusion}

Refractory castable specimens were formulated using ferrochrome slag as an aggregate and commercial calcium aluminate cement as a binder. Mechanical and thermo-physical properties of the cured, dried and sintered specimens were characterized. The effect of $\mathrm{FeCr}$ slag on the properties of refractory specimens was investigated and compared with conventional, commercial reference material targeted for similar applications. From the findings of the study, the following conclusions can be drawn:

- The liquid phase formation above $1200{ }^{\circ} \mathrm{C}$ limits the $\mathrm{FeCr}$ slag use as aggregate in refractory castables, thus the maximum service temperature for these novel slagbased refractory materials is $1200{ }^{\circ} \mathrm{C}$.

- Cold crushing strength value of $\mathrm{FeCr}$ slag-containing specimens was as high as $91 \mathrm{MPa}$.

- FeCr slag-based specimens sustained their mechanical strength also at high temperatures, with the mechanical strength values at $1200^{\circ} \mathrm{C}$ being as high as $9 \mathrm{MPa}$.

- Thermal properties of the FeCr slag based specimens were even better than those of commercial refractory reference, showing thermal conductivity values as low as $1.3 \mathrm{~W} / \mathrm{m} \mathrm{K}$.

- FeCr slag-based castables exhibited linear thermal expansion and a low thermal expansion coefficients as low as $\alpha_{\mathrm{RT}-1100{ }^{\circ} \mathrm{C}}=8.6 \times 10^{-6} 1 / \mathrm{K}$.
- FeCr slag-based castables were exposed to corrosive gas mixture with $15 \%$ humidity and $\mathrm{HCl} / \mathrm{SO}_{\mathrm{x}}$ at $700{ }^{\circ} \mathrm{C}$ for $168 \mathrm{~h}$. With visual inspection, no corrosion effects were seen on the surface of the test samples. Corrosion exposure caused no effect on strength values.

Results suggested the feasibility of ferrochrome slag to be used as an aggregate raw material for refractory materials up to temperatures of $1200{ }^{\circ} \mathrm{C}$ in air and in acidic gaseous atmosphere up to $700{ }^{\circ} \mathrm{C}$ to substitute virgin raw materials. Possible applications for this kind of novel refractory materials are, e.g., insulating secondary layers or bottom zones in metallurgical processes up to $1200{ }^{\circ} \mathrm{C}$. A direct contact to molten metal in steel industry must be avoided, but they are applicable as, e.g. floorings when exposed only to occasional melt droplets.

Acknowledgements Open access funding provided by Technical Research Centre of Finland (VTT). The research was has received funding from the European Union's H2020 programme Waste-1-2014, project RESLAG (GA-642067 and by the Strategic Research Council at the Academy of Finland, project CloseLoop, funding decision \#303453.

Open Access This article is licensed under a Creative Commons Attribution 4.0 International License, which permits use, sharing, adaptation, distribution and reproduction in any medium or format, as long as you give appropriate credit to the original author(s) and the source, provide a link to the Creative Commons licence, and indicate if changes were made. The images or other third party material in this article are included in the article's Creative Commons licence, unless indicated otherwise in a credit line to the material. If material is not included in the article's Creative Commons licence and your intended use is not permitted by statutory regulation or exceeds the permitted use, you will need to obtain permission directly from the copyright holder. To view a copy of this licence, visit http://creativecommons.org/licenses/by/4.0/.

\section{References}

1. McCaffrey, R.: Review of 11th global slag conference. https:// www.globalslag.com/conferences/global-slag/review/global-slagreview-2016 (2016). Accessed 22 May 2019

2. Yüksel, İ.: A review of steel slag usage in construction industry for sustainable development. Environ. Dev. Sustain. 19(2), 369-384 (2017)

3. Dhoble, Y.N., Ahmed, S.: Review on the innovative uses of steel slag for waste minimization. J. Mater. Cycles Waste Manage 20(3), 1373-1382 (2018)

4. Niemelä, P., Kauppi, M.: Production, characteristics and use of ferrochromium slags, pp. 171-179. INFACON XI, New Delhi (2007)

5. Zelić, J.: Properties of concrete pavements prepared with ferrochromium slag as concrete aggregate. Cem. Concr. Res. 35(12), 2340-2349 (2005)

6. Lind, B.B., Fällman, A.M., Larsson, L.B.: Environmental impact of ferrochrome slag in road construction. Waste Manage. 21, 255-264 (2001)

7. Panda, C.R., Mishra, K.K., Panda, K.C., Nayak, B.D., Nayak, B.B.: Environmental and technical assessment of ferrochrome 
slag as concrete aggregate material. Constr. Build. Mater. 49, 262-271 (2013)

8. Acharya, P.K., Patro, S.K.: Utilization of ferrochrome wastes such as ferrochrome ash and ferrochrome slag in concrete manufacturing. Waste Manage. Res. 34(8), 764-774 (2016)

9. Yilmaz, A., Karaşahin, M.: Mechanical properties of ferrochromium slag in granular layers of flexible pavements. Mater. Struct. Constr. 43(3), 309-317 (2010)

10. Dash, M.K., Patro, S.K., Rath, A.K.: Sustainable use of industrial-waste as partial replacement of fine aggregate for preparation of concrete-a review. Int. J. Sustain. Built Environ. 5(2), 484-516 (2016)

11. Dash, M.K., Patro, S.K.: Effects of water cooled ferrochrome slag as fine aggregate on the properties of concrete. Constr. Build. Mater. 177, 457-466 (2018)

12. Gencel, O., Sutcu, M., Erdogmus, E., Koc, V., Cay, V.V., Gok, M.S.: Properties of bricks with waste ferrochromium slag and zeolite. J. Clean. Prod. 59, 111-119 (2013)

13. Kumar, A., Srivastava, P.H., Kumar, V., Singh, V.K.: Implementation of industrial waste ferrochrome slag in conventionaland low cement castables: effect of calcined aluminao title. J. Asian Ceram. Soc. 2, 371-379 (2014)

14. Kumar, P.H., Srivastava, A., Kumar, V., Majhi, M.R., Singh, V.K.: Implementation of industrial waste ferrochrome slag in conventional and low cement castables: effect of microsilica addition. J. Asian Ceram. Soc. 2(2), 169-175 (2014)

15. Fang, H., Smith, J.D., Peaslee, K.D.: Study of spent refractory waste recycling from metal manufacturers in Missouri. Resour. Conserv. Recycl. 25(2), 111-124 (1999)

16. Banerjee, S., Schacht, C.A. (eds.): Refractories Handbook. Taylor \& Francis Group, Milton Park (2004)

17. Guéguen, E., Hartenstein, J., Fricke-begemann, C.: Raw material challenges in refractory application. In: Proc. Berliner Konf. Miner. Nebenprodukte und Abfaelle (2004), pp. 489-502.
18. European Refractories Producers' and Federation: Refractory ceramics and industrial minerals are critical for european industry, vol. 32. (2009).

19. Horckmans, L., Nielsen, P., Dierckx, P., Ducastel, A.: Recycling of refractory bricks used in basic steelmaking: a review. Resour. Conserv. Recycl. 140, 297-304 (2019)

20. Fennis, S.A.A.M., Walraven, J.C.: Using particle packing technology for sustainable concrete mixture design. Heron 57(2), 73-101 (2012)

21. Myhre, B, Hundere, A.M.: The use of particle size distribution in development of refractory castables. In: Proc. XXV ALAFAR Congr. pp. 1-4, (1996).

22. BASF Construction Solutions GmbH: General Information regarding refractory castable application. https://www.dispe rsions-pigments.basf.com/portal/streamer?fid=823868 (2016). Accessed 29 June 2019. .

23. European Standard: EN 196-1, Methods of testing cement; determination of strength. (1987)

24. Makkonen, H.T.: Tanskanen, Outokumpu Chrome Oy: n Ferrokromikuonan mineralogia ja liukoisuusominaisuudet. University of Oulu (2005).

25. Ortega-Fernández, I., Faik, A., Mani, K., Rodriguez-Aseguinolaza, J., D’Aguanno, B.: Experimental investigation of solid byproduct as sensible heat storage material: characterization and corrosion study. AIP Conf. Proc. 1734(May), 2016 (2016)

Publisher's Note Springer Nature remains neutral with regard to jurisdictional claims in published maps and institutional affiliations.

\section{Affiliations}

\section{Marjaana Karhu ${ }^{1}$ (D) Bob Talling ${ }^{2}$ - Patrycja Piotrowska ${ }^{2} \cdot$ Alba Matas Adams $^{3} \cdot$ Abirami Sengottuvelan $^{4}$. Elina Huttunen-Saarivirta ${ }^{1}$. Aldo R. Boccaccini ${ }^{4} \cdot$ Pertti Lintunen ${ }^{1}$}

1 VTT Technical Research Centre of Finland Ltd, P.O. Box 1300, 33101 Tampere, Finland

2 Renotech Oy, Raisionkaari 55, 21200 Raisio, Finland

3 Imperial College London (UK), Prince Consort Road, London SW7 2BP, UK
4 FAU Friedrich-Alexander University of Erlangen-Nuremberg, Cauerstr. 6, 91058 Erlangen, Germany 